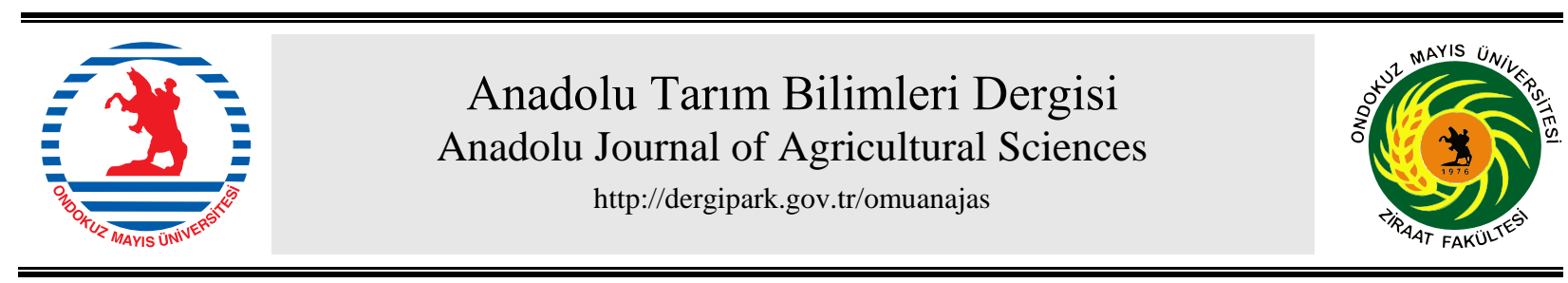

\section{Araştırma/Research}

Anadolu Tarım Bilim. Derg./Anadolu J Agr Sci, 35 (2020) ISSN: 1308-8750 (Print) 1308-8769 (Online) doi: $10.7161 /$ omuanajas. 627038

\title{
Bitki Koruma Makineleri Kullanımının Tarımda İş Güvenliği Açısından Değerlendirilmesi
}

\author{
Uğur Temel ${ }^{\mathrm{a}}$, Yeşim Benal Öztekin ${ }^{\mathrm{a}^{*}}$ \\ ${ }^{a}$ Ondokuz Mayıs Üniversitesi, Ziraat Fakültesi, Tarım Makineleri ve Teknolojileri Mühendsiliği Bölümü, Samsun, Türkiye
}

*Sorumlu yazar/corresponding author: yurtlu@omu.edu.tr

Geliş/Received 30/09/2019 Kabul/Accepted 25/11/2019

\begin{abstract}
ÖZET
Tarım sektörü, gelişmiş ülkeler de dâhil olmak üzere birçok ülkede en tehlikeli sektörlerden biri durumundadır. Tarım makineleri kazaları ile pestisitler ve diğer kimyasallara maruz kalma, sektördeki ölüm, yaralanma ve hastalıkların iki temel nedenidir. Genel olarak tarım makineleri ve özelde kimyasal uygulaması yaparak tarımsal mücadelede kullanılan makinelerle ilgili kaza, yaralanma ve hastalıkların azaltılması konularında yapılacak çalışmaların belirlenebilmesi için, çiftçilerin kullanım alışkanlıkları yönünden durumlarının analiz edilmesi gerekmektedir. Bu çalışmada, Tokat İlinde yoğun olarak kullanılan bitki koruma makinelerinin kullanımları sırasında ortaya çıkan iş güvenliği problemleri açısından incelenmesi ve bu makineleri kullanan çiftçilerin iș sağlığı ve güvenliği kurallarına uyma derecelerinin belirlenmesi amaçlanmıştır. $\mathrm{Bu}$ amaçla Tokat İl'inde Zile, Artova, Erbaa ve Niksar ilçelerinde bitki koruma makineleri kullanan çiftçiler ile yüz yüze görüşmeler yoluyla anket çalışması yürütülmüştür. Elde edilen veriler SPSS paket programında istatistiksel analize tabi tutularak bulgular ortaya konulmuştur.
\end{abstract}

\section{Evaluation of Plant Protection Machinery Using from the Point of Agricultural Safety}

\begin{abstract}
The agricultural sector is one of the most dangerous in many countries, including developed countries. Accidents in agricultural machinery and exposure to pesticides and other chemicals are the two main causes of death, injury and disease in the sector. In order to determine the works to be carried out in order to reduce the accidents, injuries and diseases related to agricultural machines in general by using agricultural machines and especially chemical applications, the situation of farmers in terms of usage habits should be analyzed. In this study, it was aimed to investigate the occupational safety problems that occur during the use of plant protection machines which are used extensively in Tokat Province and to determine the degree of compliance with the occupational health and safety rules of the farmers using these machines. For this purpose, a questionnaire was conducted through face to face interviews with farmers using plant protection machines in Zile, Artova, Erbaa and Niksar districts in Tokat. The obtained data were analyzed statistically in SPSS package program and the findings were presented.
\end{abstract}

Anahtar Sözcükler: Pestisit Uygulama Pülverizatör Tarımda İş Sağlı̆̆ ve Güvenliği
Keywords:

Pesticide Application Sprayer Health and Safety in Agriculture 


\section{Giriş}

Pestisit uygulamaları doğru olarak yapılmadığında insan sağlığ 1 ve çevre üzerinde önemli derecede zarar verici etkilere sahip olabilmektedir. Bu kimyasalların uygulanmasında kullanılan bitki koruma makinelerinin doğru ve sürdürülebilir kullanımı son derece önemlidir. Tarımsal mücadelede kullanılan pestisitlerin uygulanmasında, başta insan sağlığı ve güvenliği olmak üzere, çevresel etkiler ve gıda güvenliği göz önüne alındığında, uyulması gereken teknikler, şartlar ve iş sağlığı ve güvenliği açısından kurallar bulunmaktadır. Uygulama teknikleri, kullanılan doz, uygulanma zamanı ve koşulları, hem etkili mücadelenin yapılması hem de insan sağll $\breve{g} 1$ ve güvenliği, çevresel etkiler ve gida güvenliğini belirleyici unsurlar olarak karşımıza çıkmaktadır. Pestisitlerin üretimi, depolanması, taşınması ve satışında çalışan, pestisitleri kullanan, pestisit kalıntıları içeren gıdalarla beslenen ve çevreye bulaşan pestisitlere maruz kalan kişiler, pestisitlerden önemli derecelerde zarar görmektedir. İnsanların pestisitlerle teması, karışımın hazırlanması ve uygulanmaları sırasında olabildiği gibi ilaçlama sonrası boş ilaç kutuları, ilaç artıkları vb kalıntılarla temas sonucunda da ortaya çıkmaktadır. Tarımsal mücadele yapılırken özellikle makinelerin kullanımı sırasında pestisitler insan vücuduna; cilde temas, ağız ve solunum yoluyla olmak üzere üç farklı şekilde girmektedir. Uygulama sırasında pestisitler, çiftçilerin yeteri kadar koruyucu tedbir almamaları, genellikle günlük kıyafetlerle uygulama yapmaları ve pestisitlerin kıyafetlere bulaşma olasılığının oldukça yüksek olması gibi nedenlerle insanlara bulaşabilmektedir. Pestisitlerin çevre üzerine olan olumsuz etkilerini tamamen ortadan kaldırmak mümkün olmamakla birlikte gerekli güvenlik önlemleri alınarak etkisi azaltılabilir.

Az gelişmiş ülkelerde tarımda iş sağlığı ve güvenliği kültürünün yerleşmesi ve yaygınlaşmasını engelleyen unsurların başında, tarımsal alanda çalışan kişilerin eğitim seviyesinin son derece düşük olması gelmektedir. $\mathrm{Bu}$ durum çiftçilerin teknik bilgi açısından yetersiz kalmalarına neden olmakta, yenilikleri ve gelişmeleri takip etmelerini engellemekte, iş sağlığı ve güvenliği konusunda yeterli bilgi sahibi olamamalarına neden olmaktadir.

Tarımsal faaliyetler sirasında kullanılan bitki koruma makineleri ve kimyasallar sektörde yaşanan ölüm, yaralanma ve hastalıkların ana nedenleridir (Yurtlu ve ark., 2015). Tarımda iş sağllğı ve güvenliği ile ilgili sorunlar sadece makinelerle çalışma sırasında değil tamir, bakım, temizleme, depoyu doldurmaboşaltma ve tıkanıklıkları giderme vb işlemler sırasında da yaşanmaktadır. Tarımda yaşanan iş güvenliği sorunlarının azaltılması için gelişmiş ülkelerde risk unsurlarının belirlenmesi ve en aza indirilmesi için yoğun çaba sarf edilmektedir. Tarımda sağlık ve güvenliği tesis etmek için piyasada güvenli ürün bulundurulması, çalışanların bilinçlendirilmesi için eğitimler düzenlenmesi ve iş güvenliği kurallarının benimsenmesi gibi bir dizi tedbir alınmaktadır. Türkiye gibi gelişmekte olan ülkelerde ise tarım çalışanlarının mesleki beceri ve eğitim açısından yetersiz olmaları, çalışanların bilinçlendirilmemesi, eğitim çalışmalarının eksikliği ve iş sağllğ̆ ve güvenliği ile ilgili kurallar ve önlemlerin ilgili kişiler tarafından önemsenmemesi gibi nedenlerle çalışanlar büyük risk altındadır.

Ahioğlu (2008), yaptığı çalışmada İş Kanunu kapsamında olmayan tarım sektörünü incelemeyi amaçlamıştır. Türkiye'de tarım sektörünü iş sağlığı ve güvenliği açısından incelemiş ve tarım sektöründeki tehlikeleri ergonomi, gürültü, havalandırma, kimyasallar, psikolojik stres vb olduğunu belirlemiş ve bu tehlikelerden kimyasalları (pestisit) kapsamlı ve ayrıntılı olarak açıklamıştır. Bayat ve Andırın (2005), yaptığı araştırmada, Avrupa ülkelerinde pülverizatörlerin zorunlu denetime tabi olduğunu, ülkemizde zorunlu denetime tabi tutulması durumunda karşılaşılabilecek sorunlara ait temel verileri tespit etmeyi amaçlamış, çiftçilerin pülverizatör kullanımı konularında yeterli bilgi birikimine sahip olmadıklarını belirlemişlerdir. Araştırmalarında aşırı doz kullanımının çevre kirliliğine neden olduğunu belirtmişlerdir. Önerilen dozun altında ve üzerinde kullanımın neden olduğu sorunları ortaya koymuş, bu olumsuzlukları önlemek için pestisit uygulamalarında kullanılan ekipmanların doğru seçilmesi ve dozun doğru ayarlanması gerektiğini belirtmiştir. Demir (2005), çalışmasında Tekirdağ ili ve çevresinde yer alan tarımsal işletmelerin, ilaçlama makineleri açısından mekanizasyon durumu, makineler ile ilgili sorunları ve bu makinelerin bakım, onarım, satın alma vb. ihtiyaçlarını nası belirlediklerini saptamayı amaçlamıştır. Bu amaçla çiftçilerle anketler yapılmış, bu doğrultuda sorunlar tespit edilmeye çalışılmıştır. Anket sonuçlarına göre, çiftçilerin makinelerin bakım ve ayarlarına dikkat etmedikleri, eksikliklerini giderebilmek için ilgili kuruluşların eğitim seminerleri vermeleri durumunda bunlara katılmak istediklerini belirttiklerini ortaya koymuştur. Öz (2005), yaptığı çalışmada, Ege Bölgesi'nde meydana gelen traktör kazalarının tarımsal iş güvenliği açısından değerlendirmiştir. Anket sonuçları ve yaşanan kazaların incelendiği bu çalışmada çiftçilerin güvenli traktör kullanımı konusunda yeterince bilgilerinin olmadığ görülmüştür. Peker ve Özkan (1995), yaptıkları çalışmada, traktör ve tarım makineleri ile yapılan kazalarda meydana gelen can kayıplarına ilişkin risk analizi yapmışlardır. En önemli risk kaynağının traktör kullanımı ve kuyruk milinden hareket alan tarım makineleri olduğunu tespit etmişlerdir. Tarım makineleri ile çalışma esnasında ölümle sonuçlanan kazalarla siras1 ile en fazla \%25 harman makineleri, $\% 18$ tarım arabası ve $\% 10$ pülverizatörler ile çalışmada karşılaşıldığını belirtmişlerdir. Yurtlu ve ark. (2012), yaptıkları araştırmada, tarım makinesi kullanıcılarının 
tarım makineleri kullanımına ilişkin risk algılarını belirlemeyi amaçlamışlardır. Bu amaç doğrultusunda çiftçilerle anket yapılmış, onların eğitim ve beceri durumları ile birlikte tarım makineleri kullanımına ilişkin risk algıları değerlendirilmiştir. $\mathrm{Bu}$ anketler doğrultusunda tarımda yaşanan kazaları azaltmaya yönelik öneriler sunulmuş, araştırma sonucunda, tarım makineleri kaza riskleri konusunda mevcut durumun değişmeden devam ettiği belirlenmiş, ayrıca makineleri güvenli kullanım konusunda eğitim düzeyi düşük kişiler, kadınlar, çocuklar ve diğer kişilerin kazalardan olumsuz etkilendikleri tespit edilmiştir. Kullanıcılara verilecek makine kullanımı konusunda eğitimlerin kazaları azaltacağı vurgulanmıştır.

Bitki koruma makineleri, hem bir tarım makinesi olarak kazalara sebebiyet vermesi açısından hem de kimyasal uygulamada kullanılan bir makine olması nedeniyle, etkili tarımsal mücadele yapılmasındaki öneminin yanı sıra, operatörlerin sağlık ve güvenliği, çevresel etkiler ve gıda güvenliği gibi çok yönlü önem ve etkileri olan makinelerdir. Peker ve Özkan (1995) yapmış oldukları bir araştırmada, pülverizatörle çalışmada kazalarda ölüm oranın diğer tarım makineleri arasında \%10 gibi önemli bir paya sahip olduğunu bildirmişlerdir. $\mathrm{Bu}$ makine grubu pestisit uygulamasında kullanılan makineler olduğu için operatörlerin meslek hastalıklarına yakalanması açısından da son derece risklidir. $\mathrm{Bu}$ nedenlerle bitki koruma makinelerini kullanırken iş güvenliğine özel önem göstermek gerekmektedir. $\mathrm{Bu}$ araştırmanın amacı, pilot il olarak belirlenen Tokat'ta bitki koruma makinelerini kullanan çiftçilerin, kullanım alışkanlıkları ile iş sağlığı ve güvenliği kurallarına uyma durumlarını inceleyerek iş güvenliği açısından bir değerlendirme yapmaktır.

\section{Materyal ve Yöntem}

Araştırma materyalini, Tokat İli Zile, Artova, Erbaa ve Niksar ilçelerinde çiftçilerden anket yoluyla elde edilen bilgiler ve araştırma bölgesinde yapılan gözlemler oluşturmaktadır. Anketler, 2016 yılı Mart, Nisan ve Haziran aylarında yapılmıştır. Anket çalışması yapılacak ilçeler belirlenirken, bitki koruma makinelerinin yoğun olarak kullanılma durumu ve Tarım ve Orman Bakanlığı Çiftçi Kayıt Sistemi (ÇKS) verileri referans alınmıştır. $\mathrm{Bu}$ araştırmada anket verilerinin elde edilmesinde Tokat İlini temsil eden, bitki koruma makinelerinin yoğun olarak kullanıldığı Zile, Artova, Erbaa ve Niksar ilçeleri seçilmiştir. Örnek büyüklüğü belirlenirken ÇKS verilerinden yola çıkılarak 4 ilçedeki çiftçilerden araştırmada hata payı $\% 5$ olarak kabul edilerek \% 95 güven derecesinde 164 adet örnek sayıs1 tesadüfi örnekleme yöntemi ile belirlenmiştir. Optimum örnek hacmi hesaplamasında aşağıda yer alan Eşitlik 1 kullanılmıştır (Yamane, 1967):

$$
n=\frac{N \sum N_{h} S_{h}^{2}}{N^{2} D^{2}+\sum N_{h} S_{h}^{2}}
$$

Eşitlikte; n: anket yapılacak işletme sayısını, N: ana kitlede bulunan işletme sayısını, Nh: her bir tabakadaki işletme sayısını, Sh: her bir tabakadaki standart sapmayı ve D: araştırmada izin verilen hata payını ile ifade etmektedir.

Yapılan anketlerin ilçelere göre dağılımı ve yüzdeleri, Çizelge 1'de yer almakta olup ÇKS verilerindeki çiftçi sayılarına göre hazırlanmıştır.

Çizelge 1. Anket yapılan ilçeler ve anketlerin sayısal dağılımı

Table 1. Districts and number of survey

\begin{tabular}{ccc}
\hline İlçeler & $\begin{array}{c}\text { Anket Sayıs1 } \\
\text { (Adet) }\end{array}$ & $\begin{array}{c}\text { Dağılım Oranı } \\
(\%)\end{array}$ \\
\hline Zile & 53 & 32.3 \\
Erbaa & 46 & 28.0 \\
Niksar & 38 & 23.2 \\
Artova & 27 & 16.5 \\
\hline Toplam & 164 & 100 \\
\hline
\end{tabular}

Anket soruları araştırmanın amacına göre geliştirilmiştir. Anket formlarının işlenebilirliğini test etmek için önce pilot çalışma uygulanmış, bazı sorular araştırmaya uygun olmadığ 1 düşünülerek anket formundan çıkartılmış ve araştırmaya uygun olduğu varsayılan sorular ise anket formuna eklenmiştir. Anketler, araştırmacılar tarafindan bitki koruma makinesi kullanan çiftçilerle birebir görüşmeler yoluyla yürütülmüştür. Anket yapılırken, görüşülen kişilere anlaşılmayı pekiştirmek için bazı sorular açıklanmış, böylece soruların yanlış anlaşılma durumu ortadan kaldırılarak elde edilen verilerin güvenilirliği ve doğruluğu arttırılmaya çalışılmıştır. Anket çalışması için görüşme yapılan çiftçiler Zile, Artova, Erbaa ve Niksar ilçelerinde bitki koruma makinesi kullanan çiftçilerden tesadüfi olarak belirlenmiştir. Anket formlarında yer alan veriler SPSS paket programında analiz edilmişsir.

\section{Bulgular ve Tartışma}

\section{1 İşletme Sahipleri ile İlgili Bilgiler}

Bitki koruma makinesi kullanan çiftçilere ait bilgiler Çizelge 2'de yer almaktadır. Bitki koruma makinesi kullanıcıları genellikle orta yaşta olup erkektir. Kadınlar bu makineleri kullanırken erkeklere yardımeı olmaktadır. Bitki koruma makinesini kullanan çiftçilerin eğitim seviyesine bakıldığında \%47'si ilkokul mezunu, $\% 29.9$ 'u ortaokul mezunu, \%19.5'i lise mezunu, $\% 0.6$ 's1 üniversite mezunu iken \%3.0'1 okuryazardır. Kullanıcı çiftçilerin tamamı sürekli köyde ikamet etmektedir. Çiftçilerin \%75.0'ı ziraat mühendisi, Tarım ve Orman il ve ilçe müdürlüğü ve komşu çiftçilerin 
Çizelge 2. Bitki koruma makinesi kullanıcılarına ait bilgiler

Table 2. Information about plant protection machinery users

\begin{tabular}{|c|c|c|c|}
\hline Çiftçilere Ait Bilgiler & & Kişi Sayıs1 & $\begin{array}{c}\text { Dağılım } \\
\text { Oranı } \\
(\%)\end{array}$ \\
\hline \multirow{5}{*}{ Eğitim seviyesi } & Okuryazar olan & 5 & 3.0 \\
\hline & İlköğretim & 77 & 47.0 \\
\hline & Ortaöğretim & 49 & 29.9 \\
\hline & Lise & 32 & 19.5 \\
\hline & Üniversite & 1 & 0.6 \\
\hline \multirow{5}{*}{ Sosyal güvence } & Yok & 32 & 19.5 \\
\hline & Bağ-Kur & 82 & 50.0 \\
\hline & SSK & 12 & 7.3 \\
\hline & Yeşil kart & 2 & 1.2 \\
\hline & Emekli & 36 & 22.0 \\
\hline \multirow{3}{*}{ İkamet yeri } & Köy & 164 & 100.0 \\
\hline & İlçe merkezi & 0 & 0 \\
\hline & Şehir & 0 & 0 \\
\hline \multirow{2}{*}{ Üretici birliği, dernek veya kooperatif üyeliği } & Üye & 80 & 48.8 \\
\hline & Üye değil & 84 & 51.2 \\
\hline \multirow{2}{*}{ Tarımsal konularda başkalarına danışma durumu } & Evet & 123 & 75.0 \\
\hline & Hayır & 41 & 25.0 \\
\hline \multirow{2}{*}{$\begin{array}{l}\text { Tarım teşkilatlarının yeterince yardımcı olduğunu düşünme } \\
\text { durumu }\end{array}$} & Evet & 103 & 62.8 \\
\hline & Hayır & 61 & 37.2 \\
\hline \multirow{2}{*}{$\begin{array}{l}\text { Tarım makinelerinin güvenli kullanımı konusunda eğitim } \\
\text { alma durumu }\end{array}$} & Evet & 9 & 5.5 \\
\hline & Hayır & 155 & 94.5 \\
\hline \multirow{2}{*}{ Tarımsal kuruluşlarla iş birliği durumu } & Evet & 79 & 48.2 \\
\hline & Hayır & 85 & 51.8 \\
\hline \multirow{2}{*}{$\begin{array}{l}\text { Tarımsal konularla ilgili toplantı, eğitim, kurs, sempozyum ve } \\
\text { konferanslara katıllm durumu }\end{array}$} & Evet & 95 & 57.9 \\
\hline & Hayır & 69 & 42.1 \\
\hline \multirow{2}{*}{ Tarımsal konularda belge ve sertifika alma durumu } & Evet & 13 & 7.9 \\
\hline & Hayır & 151 & 92.1 \\
\hline
\end{tabular}

tarımsal konularda bilgisine başvururken, \%25.0’1 başkalarının bilgisine başvurmayıp kendi bilgilerine güvenmektedir. Tokat İl'inde çiftçilerin $\% 94.5$ 'i bitki koruma makinelerinin güvenli kullanımı konusunda eğitim almamıştır. Anket yapılan çiftçilerin \%57.9'u tarımsal konularla ilgili toplantı, eğitim, kurs vb katılmış, \%42.1'i hiç katılmamıştır.

\subsection{Hastalık, Zararlı ve Yabancı Otlarla Mücadele ile Ilgili Bilgiler}

Bitki koruma makinesi kullanan çiftçilerin hastalık, zararlı ve yabancı otlarla mücadele yöntemlerine ait bilgiler Çizelge 3'de yer almaktadır. Çizelge 3 incelendiğinde Tokat İl'inde bitki koruma makinelerini kullanan çiftçilerin \%53.7'sinin zararlıdan örnek alıp Tarım ve Orman İlçe müdürlüğü, özel tarım danışmanı, ziraat mühendisi, ilaç bayii ve Tarım Kredi Kooperatifine incelemeye götürdüğü, çiftçilerin tamamının bitkilerde bulunan hastalık ve zararlılarla ilgili mücadele yöntemlerinden kimyasal mücadele yöntemini tercih ettiği belirlenmiştir. Kimyasal mücadele yöntemini, çiftçilerin\%21.3'ü uygulamanın kolay olması, \%3.7'si sonucun gözle görülebilir olması, $\% 46.4$ 'ü kısa sürede sonuç vermesi, $\% 28.0$ '1 ziraat mühendisi ve tarım danışmanın tavsiyesi, \%0.6'sı ise komşu çiftçilerin tavsiyesi ile tercih ettiğini belirtmiştir. Çiftçilerin \%97'si hastalı̆̆ görmeden ilaçlama yapmadığını ifade etmiştir. Çiftçilerin \% 51.8'i hastalığı görür görmez ilaçlama yapmaktadır. Çiftçiler kimyasal ilaçlama sırasında kullanılan ilaç dozunu \%9.8'i bayii ve teknik elemanların önerisi ile \%38.4'ü kutuların üzerinde yazılı olan bilgiye göre, \%45.7'si kendi tecrübelerine dayanarak, $\% 6.1$ ' $\mathrm{i}$ ziraat mühendisine danışarak ayarlamaktadır. Çiftçilerin \%38.4'ünün kullanılan kimyasalın dozunu kimyasal kutuların üzerinde yazan etiket bilgisine göre ayarladığı, \%64.6'sının etiket bilgisine önem vermediği tespit edilmiştir. İlaç kalıntılarının insanlara zararlı olma durumuna dair soruya çiftçilerin \%97.0'1 zararlıdır derken \%3’ü bilgisinin olmadığını belirtmiştir. Kullanılan ilaçların çevreye zararlı olma durumu sorulduğunda çiftçilerin \%93.9'u zararlı olduğunu ifade etmiş, \%6.1'i bilgisinin olmadığını belirtmiştir. Bitki 
Çizelge 3. Zararlılarla mücadele ile ilgili bilgiler

Table 3. Information about plant protection methods

\begin{tabular}{|c|c|c|c|}
\hline \multicolumn{2}{|c|}{ Çiftçilere Ait Bilgiler } & \multirow{2}{*}{$\begin{array}{c}\text { Kişi Sayıs1 } \\
88\end{array}$} & \multirow{2}{*}{$\begin{array}{c}\begin{array}{c}\text { Dağ } 111 \mathrm{~m} \\
\text { Oranı } \\
(\%)\end{array} \\
53.7\end{array}$} \\
\hline \multirow{2}{*}{ Zararlıdan örnek alma ve inceletme durumu } & Evet & & \\
\hline & Hayır & 76 & 46.3 \\
\hline \multirow{6}{*}{$\begin{array}{l}\text { Bitkilerde bulunan hastalık ve zararlıyla } \\
\text { mücadelede en çok kullanılan metot }\end{array}$} & Kültürel yöntemler & 0 & 0 \\
\hline & Fiziksel ve mekanik yöntemler & 0 & 0 \\
\hline & Biyolojik yöntemler & 0 & 0 \\
\hline & Biyoteknik yöntemler & 0 & 0 \\
\hline & Kimyasal mücadele yöntemler & 100 & 100 \\
\hline & Entegre mücadele yöntemler & 0 & 0 \\
\hline \multirow{5}{*}{$\begin{array}{l}\text { Kimyasal mücadele yöntemini tercih etme } \\
\text { durumu }\end{array}$} & Uygulamanın kolay olması & 35 & 21.3 \\
\hline & $\begin{array}{l}\text { Sonucun gözle görülebilir } \\
\text { olması }\end{array}$ & 6 & 3.7 \\
\hline & Kısa sürede sonuç vermesi & 76 & 46.4 \\
\hline & $\begin{array}{l}\text { Ziraat mühendisi ve tarım } \\
\text { danışmanının tavsiyeleriyle }\end{array}$ & 46 & 28.0 \\
\hline & Komşu çiftçilerin tavsiyeleriyle & 1 & 0.6 \\
\hline \multirow{2}{*}{ Hastalığı görmeden ilaçlama durumu } & Evet & 5 & 3.0 \\
\hline & Hayır & 159 & 97.0 \\
\hline \multirow{2}{*}{ Hastalığı görür görmez ilaçlama durumu } & Evet & 85 & 51.8 \\
\hline & Hayır & 79 & 48.2 \\
\hline \multirow{5}{*}{ Kullanılan pestisitin dozunu ayarlama } & Bayii ve teknik eleman önerisi & 16 & 9.8 \\
\hline & $\begin{array}{l}\text { Kutuların üzerinde yazilı olan } \\
\text { etiket bilgisi }\end{array}$ & 63 & 38.4 \\
\hline & Kendi tecrübem & 75 & 45.7 \\
\hline & Komşu çiftçilere sorma & 0 & 0 \\
\hline & Ziraat Mühendisine danışma & 10 & 6.1 \\
\hline \multirow{2}{*}{$\begin{array}{l}\text { İlaç kutularının üzerindeki bilgiye önem } \\
\text { verme durumu }\end{array}$} & Evet & 63 & 38.4 \\
\hline & Hayır & 101 & 61.6 \\
\hline \multirow{3}{*}{$\begin{array}{l}\text { İlaç kalıntılarının insanlara zararlı olma } \\
\text { durumu }\end{array}$} & Zararlıdır & 159 & 97.0 \\
\hline & Zararlı değildir & 0 & 0 \\
\hline & Bilgim yok & 5 & 3.0 \\
\hline \multirow{3}{*}{$\begin{array}{l}\text { Kimyasal ürünlerin çevreye zararlı olma } \\
\text { durumu }\end{array}$} & Evet & 154 & 93.9 \\
\hline & Hayır & 0 & 0 \\
\hline & Bilgim yok & 10 & 6.1 \\
\hline \multirow{2}{*}{ İlacın uygulandığı alan durumu } & Tüm alana & 83 & 50.6 \\
\hline & Hastalık-zararlı olan alana & 81 & 49.4 \\
\hline \multirow{3}{*}{$\begin{array}{l}\text { Ziraat Mühendisi } \\
\text { gereksiz dediğinde }\end{array}$} & Ziraat Mühendisini dinlerim & 77 & 46.9 \\
\hline & Başkasına danışır karar veririm & 17 & 10.4 \\
\hline & Yine de uygularım & 70 & 42.7 \\
\hline \multirow{3}{*}{$\begin{array}{l}\text { Kimyasal mücadelede zehirlenmelere en çok } \\
\text { maruz kalınan yol }\end{array}$} & Solunum yoluyla & 125 & 76.2 \\
\hline & Deri yoluyla & 27 & 16.5 \\
\hline & Ağız yoluyla & 12 & 7.3 \\
\hline
\end{tabular}

koruma makinesini kullanan çiftçilerin \%50.6's1 tüm alana, \%49.4'ü sadece zararlının bulunduğu alana ilaçlama yaptığını belirtmiştir.

Arazide bulunan hastalık, zararlı ve yabancı ot için ziraat mühendisi kimyasal mücadele gereksiz dediğinde çiftçilerin \%45.9'u ziraat mühendisini dinlerim uygulamam, \%10.4'ü bir başka çiftçiye danışır karar veririm, $\% 42.7$ 'si teknik elemanı dinlemeyip kendi tecrübeme göre ilaçlama yaparım şeklinde yanıt vermiştir.

Çiftçilerin \%76.2'si solunum yolu, \%16.5'i deri yolu, \%7.3'ü ağız yolu ile zehirlenmeye maruz kalabileceklerini belirtmişlerdir. 


\subsection{Bitki Koruma Makinelerinin Kullanımı ile Ilgili} Bilgiler

Tokat İl'inde bitki koruma makinesini kullanan çiftçilerin makine kullanımı ile ilgili bilgi durumları ve tutumları ile ilgili elde edilen veriler Çizelge 4' de yer almaktadır. Çizelge 4 incelendiğinde bitki koruma makinelerinin güvenli kullanımı konusunda çiftçilerin $\% 76.8$ 'i orta düzeyde bilgi sahibi olduklarını belirtmişlerdir. Çiftçilerin \%64.0’1 bitki koruma makinelerinin güvenli kullanımı konusunda kendi bilgilerini uygulamaktadır. Kalibrasyon hakkındaki bilgileri $\% 0.6$ çok iyi, $\% 6.1$ yeterli, $\% 14.0$ orta, $\% 17.7$ yetersiz ve \%14.0 çok kötü düzeyde olup kalibrasyonu ilk defa duyanlar ise \%47.6'dır. Çiftçilerin \%2.4'ü her zaman, $\% 20.1$ 'i ara sira, \%15.9'u nadiren kalibrasyon ayarı yaptığını, \%61.6's1 kalibrasyon ayarını yapmadığını belirtmiştir. Bitki koruma makinesini kullanan çiftçilerin $\% 69.5$ 'i her zaman, \%12.8'i ara sıra, $\% 4.9$ 'u nadiren iş öncesi makineyi kontrol ettiğini, $\% 12.8$ 'i ise hiç kontrol etmediğini belirtmiştir. Traktör ilerleme hızı, debi ve basınç kontrolünü çiftçilerin $\% 42.1$ 'i hiç yapmamakta, \%11.6'sı her zaman, \%17.7'si ara sira \%28.6's1 nadiren yapmaktadır. Makinenin kullanım öncesi ayar ve bakımını çiftçilerin \%18.3'ü her zaman, \% 31.7'si ara sıra, \%7.9'u nadiren yapmakta iken $\% 42.1$ 'i hiç yapmadığını bildirmiştir. Makinenin kullanım ve bakım kılavuzunu çiftçilerin \%23.8'i her makine için, \%20.7'si ara sıra, \%22'si nadiren okuduğunu, \%45.7'si okumadığını, \%2.4'ü ise hiç kullanım k1lavuzu görmediğini belirtmiştir. Bitki koruma makinesini kullanan çiftçiler bitki koruma ürünlerini (pestisitleri) $\% 2.4$ 'ü her zaman, $\% 30.5$ 'i ara sira, \%5.5'i nadiren kilitli bir yerde tutarken, \%61.6's1 kilit altında tutmadığını belirtmiştir. Kullanılan bitki koruma ürünlerini çiftçilerin \%13.4'ü evde kimsenin ulaşamayacağı yüksek bir yerde, \%20.1'i kimsenin bilmediği kilitli bir yerde, \%4.9'u ahırda, \%14.6's1 evin bahçesinde ve \%50'si malzeme ve traktör garajında tutmaktadır. Bitki koruma makinesini kullanan çiftçilerin makine ile tarlada kullanmadan önce \%20.1'i her zaman, \%12.8'i ara sıra, \%29.3'ü nadiren ön deneme yaptığını belirtirken, \%37.8' inin hiç deneme yapmadığı anlaşılmıștır. Makineyi kullanırken güvenlik kurallarını çiftçilerin \%20.7'si her zaman, \%61'i ara sıra, \%14.6's1 nadiren dikkate aldıklarını söylerken, \%3.7'si hiç dikkate almadığını belirtmiştir. Makinedeki güvenlik önlemleri ile ilgili bilgi düzeyleri çiftçilerin $\% 1.2$ 'sinin çok iyi, $\% 25$ 'inin yeterli, $\% 68.9$ 'unun orta, $\% 3.7$ 'sinin yetersiz ve \%1.2'sinin çok kötü olduğu anlaşılmıştır. Bitki koruma makinesini kullanan çiftçilerin \%8.5'i her zaman, \%5.5'i ara sıra, \%3.7'si nadiren kişisel koruyucu donanım kullanmakta iken \%82.3'ü hiçbir zaman kullanmamaktadır. Çiftçilerin kullandığı maskelerin \%1.8'i aktif karbon dondurulmuş nefes alma filtresi olan özellikte iken \%98.2'si bu özellikte değildir. Çiftçilerin kullandığı eldivenlerin $\% 4.9$ ’u $0.3-0.6 \mathrm{~mm}$ kalınlığında su ve kimyasal geçirmezken \%95.1’i bu özellikte değildir. Kimyasal ilaç uygulaması sırasında çiftçilerin kullandığı giysi ve iş tulumu \%4.3'su geçirmez ve kimyasallara dirençlidir, \%95.7'si değildir. Giyilen çizmeler \%3.7 doğal kauçuktan yapılmış ve kimyasallara dirençlidir, $\% 96.3$ 'ü değildir. Molalarda çiftçilerin \%50.6's1 her zaman, \%42.1'i ara sıra, \%7.3'ü nadiren ellerini sabunlu su ile yıkarken hiç yıkamayan yoktur ve molalarda çiftçilerin \%14'ü her zaman, \%70.2'si ara sıra, \%7.3'ü nadiren katı ve sıvı bir şey tüketip sigara içtiğini, \%8.5'i hiçbir şey tüketmediğini belirtmiştir.

Makineyi kullanma esnasında çiftçilerin \%6.7'si her zaman, $\% 57.3$ 'ü ara sıra, \%19.5'i nadiren çalışma esnasında tıkanan memeleri ağızla üfleyerek ya da ağızla hava emerek temizlemeye çalışmakta, $\% 16.5$ ' $\mathrm{i}$ ise memeleri bu şekilde temizlememektedir. Ciftçiler rüzgârlı havada rüzgâr hızını, \%2.4 parmağını ıslatıp rüzgara karşı tutarak, \%37.2'si meteoroloji haberlerini takip ederek, \%60.4'ü havanın rüzgarlı olduğunu görüp tahmin yürüterek belirlemektedir. Rüzgârlı havalarda ilaç yapılamaması gereken rüzgâr hızını çiftçilerin \%30.5' i bilmediğini, \%3.7'si 2 m s-1, \%6.7'si 3 m s-1, $\% 29.9$ 'u ise $4 \mathrm{~m} \mathrm{~s}-1, \% 11.6$ 's1 $5 \mathrm{~m} \mathrm{~s}-1, \% 17.7$ 'si $6 \mathrm{~m} \mathrm{~s}$ 1 olduğunu düşündüklerini söylemiştir. Çiftçilerin \%1.8'i her zaman, \%9.8'i ara sira, \%25'i nadiren rüzgarlı havalarda ilaçlama yapmaktayken, \%63.4'ü yapmamaktadır. Bitki koruma makinesini kullanan çiftçilerin $\% 87.8$ 'i her zaman, \%11'i ara sıra, \%1.2'si nadiren kimyasal mücadele uygulamasını tek seferde yarım iş gününden fazla yapmaktadır. Kimyasal ilaç uygulaması bittikten sonra çiftçiler kullandıkları eldiven, çizme, maske ve giysilerini \%2.4'ü her zaman, $\% 6.1$ 'i ara sira, \%11'i nadiren yıkamakta iken $\% 80.5$ ' $\mathrm{i}$ yıkamamaktadır ve yıkama malzemesi olarak normal bulaşık deterjanı ile sabunlu su kullanmaktadırlar. Yıkanan eldiven, çizme, maske ve giysileri çiftçilerin $\% 2.4$ 'ü ara sıra, \%1.2'si nadiren 24 saat güneş 1şı̆ 1 altında kimsenin ulaşamadığı bir yerde kurutmakta iken $\% 96.4$ 'ü kurutmamaktadır ve çiftçilerin $\% 1.8$ 'i ara sıra, $\% 1.8$ 'i nadiren naylon torbada muhafaza ederken $\% 96.4$ 'ü etmemektedir ve bu malzemeleri çiftçilerin $\% 92.7$ 'si her zaman, \%5.5'i ara sira, \%1.8'i nadiren başka işlerde kullanmakta iken başka işler için kullanmayan yoktur.

Kullanılan bitki koruma ürünlerinin kullanım sonunda boş ilaç kutularını çiftçilerin \% $\% 16.5$ 'i yaktığını, \%14.6's1 çöpe attığını, \%66.5'i tarla kenarına bıraktığını, \%1.2'si dere kenarına attığını, \%1.2'si toprağa gömdüğünü belirmiştir. Çiftçilerin tamamı kullanım sonunda boş ilaç kutularını başka işler için kullanmadığını belirtmiştir. Kullanım sonunda çiftçilerin \%29.9'u her zaman, \%31.1' $\mathrm{i}$ ara sıra, \%14.6'sı nadiren temizlerken \%18.3'ü temizlemediğini söylemişlerdir. İlaçlama yapıldıktan sonra çiftçilerin \%3.7'si her zaman, \%7.9'u ara sira, \%14.6's1 nadiren çevredeki insanları ve hayvanları otlatan insanları en az 2 gün ilaçlama yapılan alana girmemeleri konusunda 
bilgilendirdiğini, \%73.8'i hiç bilgilendirmediğini belirtmiştir. Yapılan çalışmada çiftçilerin bitki koruma makinelerinin kullanımı ile ilgili bilgi düzeylerinin orta düzeyi geçmediği tespit edilmiş, çiftçilerin makineyi kullanma sırasında, kullanım öncesi ayar, bakım ve kullanım sonunda arta kalan pestisit ve makine temizliği konularında, kişisel koruyucu donanımları kullanarak kimyasal zehirlenmeleri önleme konusunda bilgi düzeylerinin yeterli olmadığı ve güvenlik ile ilgili kuralları dikkate almadıkları tespit edilmiştir.

Çizelge 4. Bitki koruma makinelerinin kullanımı ile ilgili bilgiler

Table 4. Information about plant protection using habits

\begin{tabular}{|c|c|c|c|}
\hline \multicolumn{2}{|c|}{ Çiftçilere Ait Bilgiler } & \multirow{2}{*}{$\begin{array}{c}\text { Kişi Sayısı } \\
1\end{array}$} & \multirow{2}{*}{$\begin{array}{c}\text { Dağılım } \\
\text { Oranı } \\
(\%)\end{array}$} \\
\hline \multirow{5}{*}{$\begin{array}{l}\text { Bitki koruma makinelerinin güvenli kullanım } \\
\text { bilgisi }\end{array}$} & Çok iyi & & \\
\hline & Yeterli & 36 & 22.8 \\
\hline & Orta & 126 & 76.8 \\
\hline & Yetersiz & 1 & 0.6 \\
\hline & Çok kötü & 0 & 0 \\
\hline \multirow{6}{*}{ Kalibrasyon hakkında bilgi durumu } & Çok iyi & 1 & 0.6 \\
\hline & Yeterli & 10 & 6.1 \\
\hline & Orta & 23 & 14.0 \\
\hline & Yetersiz & 29 & 17.7 \\
\hline & Çok kötü & 23 & 14.0 \\
\hline & İlk defa duyuyorum & 78 & 47.6 \\
\hline \multirow{4}{*}{ Kalibrasyon yapma durumu } & Her zaman & 4 & 2.4 \\
\hline & Ara sira & 33 & 20.1 \\
\hline & Nadiren & 26 & 15.9 \\
\hline & Hiç yapmam & 101 & 61.6 \\
\hline \multirow{4}{*}{ İş öncesi makineyi kontrol etme durumu } & Her zaman & 114 & 69.5 \\
\hline & Ara sira & 21 & 12.8 \\
\hline & Nadiren & 8 & 4.9 \\
\hline & Hiç yapmam & 21 & 12.8 \\
\hline \multirow{4}{*}{ Traktör ilerleme hızı, debi ve basınç kontrolü } & Her zaman & 19 & 11.6 \\
\hline & Ara sira & 29 & 17.7 \\
\hline & Nadiren & 47 & 28.6 \\
\hline & Hiç yapmam & 69 & 42.1 \\
\hline \multirow{4}{*}{ İş öncesi makinede ayar ve bakım yapma } & Her zaman & 30 & 18.3 \\
\hline & Ara sira & 52 & 31.7 \\
\hline & Nadiren & 13 & 7.9 \\
\hline & Hiç yapmam & 69 & 42.1 \\
\hline \multirow{4}{*}{ Kullanım ve bakım kılavuzunu okuma } & Her zaman & 19 & 11.6 \\
\hline & Ara sira & 34 & 20.7 \\
\hline & Nadiren & 36 & 22.0 \\
\hline & Hiç okumam & 71 & 45.7 \\
\hline \multirow{4}{*}{ Pestisitlerin kilitli yerde tutulma durumu } & Her zaman & 4 & 2.4 \\
\hline & Ara sira & 9 & 5.5 \\
\hline & Nadiren & 50 & 30.5 \\
\hline & Hiç yapmam & 101 & 61.6 \\
\hline \multirow{5}{*}{ Pestisitleri saklama yeri } & Evde yüksek bir yerde & 22 & 13.4 \\
\hline & Kilitli bir yerde & 33 & 20.1 \\
\hline & Ahirda & 8 & 4.9 \\
\hline & Bahçede & 24 & 14.6 \\
\hline & Diğer (Traktör garaj1 vb) & 77 & 50.0 \\
\hline \multirow{4}{*}{ Kullanmadan önce deneme yapma } & Her zaman & 33 & 20.1 \\
\hline & Ara sira & 21 & 12.8 \\
\hline & Nadiren & 48 & 29.3 \\
\hline & Hiç yapmam & 62 & 37.8 \\
\hline \multirow{4}{*}{ Güvenlik kurallarını dikkate alma durumu } & Her zaman & 34 & 20.7 \\
\hline & Ara sira & 100 & 61.0 \\
\hline & Nadiren & 24 & 14.6 \\
\hline & Hiç dikkate almam & 6 & 3.7 \\
\hline
\end{tabular}


Çizelge 4. Devamı

Table 4. Continued

Çiftçilere Ait Bilgiler

Kişi Sayısı Dağılım

\begin{tabular}{|c|c|c|c|}
\hline \multicolumn{3}{|l|}{ Çıttçılere Ait Bılgiler } & \multirow{2}{*}{$\begin{array}{r}\text { Oran } \\
(\%) \\
1.2\end{array}$} \\
\hline \multirow{5}{*}{ Güvenlik önlemleri hakkında bilgi durumu } & Çok iyi & 2 & \\
\hline & Yeterli & 41 & 25.0 \\
\hline & Orta & 113 & 68.9 \\
\hline & Yetersiz & 6 & 3.7 \\
\hline & Çok kötü & 2 & 1.2 \\
\hline \multirow{4}{*}{ Kişisel koruyucu donanım kullanma durumu } & Her zaman & 14 & 8.5 \\
\hline & Ara sira & 9 & 5.5 \\
\hline & Nadiren & 6 & 3.7 \\
\hline & Hiç kullanmam & 135 & 82.3 \\
\hline \multirow{2}{*}{$\begin{array}{l}\text { Kullanılan maskelerin uygunluğu (aktif } \\
\text { karbonlu vb) }\end{array}$} & Evet & 3 & 1.8 \\
\hline & Hayır & 161 & 98.2 \\
\hline \multirow{2}{*}{$\begin{array}{l}\text { Kullanılan eldivenler } 0.3-0.6 \mathrm{~mm} \\
\text { kalınlığında su ve kimyasal geçirmez } \\
\text { özellikte }\end{array}$} & Evet & 8 & 4.9 \\
\hline & Hayır & 156 & 95.1 \\
\hline \multirow{2}{*}{$\begin{array}{l}\text { Giyilen giysi, iş tulumu vb hava geçirgen, } \\
\text { kimyasallara dirençli ve su geçirmez } \\
\text { özellikte }\end{array}$} & Evet & 7 & 4.3 \\
\hline & Hayır & 157 & 95.7 \\
\hline \multirow{2}{*}{$\begin{array}{l}\text { Giyilen çizmeler doğal kauçuktan yapılmış } \\
\text { ve kimyasallara dirençli özellikte }\end{array}$} & Evet & 6 & 3.7 \\
\hline & Hayır & 158 & 96.3 \\
\hline \multirow{4}{*}{ Molalarda elleri yıkama durumu } & Her zaman & 75 & 45.7 \\
\hline & Ara sira & 69 & 42.1 \\
\hline & Nadiren & 12 & 7.3 \\
\hline & Hiç yıkamam & 8 & 4.9 \\
\hline \multirow{4}{*}{$\begin{array}{l}\text { Molalarda katı, sıvı bir şey tüketme ve sigara } \\
\text { içme durumu }\end{array}$} & Her zaman & 23 & 14.0 \\
\hline & Ara sira & 115 & 70.2 \\
\hline & Nadiren & 12 & 7.3 \\
\hline & Hiçbir zaman & 14 & 8.5 \\
\hline \multirow{4}{*}{ Pülverizatör memelerini ağızla temizleme } & Her zaman & 11 & 6.7 \\
\hline & Ara sira & 94 & 57.3 \\
\hline & Nadiren & 32 & 19.5 \\
\hline & Hiçbir zaman & 27 & 16.5 \\
\hline \multirow{6}{*}{$\begin{array}{l}\text { Uygulama yapılmaması gereken rüzgâr hızı } \\
\text { bilgisi }\end{array}$} & $2 \mathrm{~m} / \mathrm{s}$ & 6 & 3.7 \\
\hline & $3 \mathrm{~m} / \mathrm{s}$ & 11 & 6.7 \\
\hline & $4 \mathrm{~m} / \mathrm{s}$ & 49 & 29.9 \\
\hline & $5 \mathrm{~m} / \mathrm{s}$ & 19 & 11.6 \\
\hline & $6 \mathrm{~m} / \mathrm{s}$ & 29 & 17.7 \\
\hline & Bilmiyorum & 50 & 30.5 \\
\hline \multirow{4}{*}{ Hava hızını ölçme yöntemi } & $\begin{array}{l}\text { Parmağımı 1slatırım rüzgâra } \\
\text { karşı tutarım }\end{array}$ & 4 & 2.4 \\
\hline & $\begin{array}{l}\text { Meteoroloji haberlerini takip } \\
\text { ederim }\end{array}$ & 61 & 37.2 \\
\hline & $\begin{array}{l}\text { Havanın rüzgârlı } \\
\text { olduğunu görür tahmin } \\
\text { ederim }\end{array}$ & 99 & 60.4 \\
\hline & Diğer & 0 & 0 \\
\hline \multirow{4}{*}{ Rüzgârlı havada ilaçlama yapma durumu } & Her zaman & 3 & 1.8 \\
\hline & Ara sira & 16 & 9.8 \\
\hline & Nadiren & 41 & 25.0 \\
\hline & Hiçbir zaman & 104 & 63.4 \\
\hline
\end{tabular}


Çizelge 4. Devamı

Table 4. Continued

Çiftçilere Ait Bilgiler

Kişi Sayısı Dağılım

\begin{tabular}{|c|c|c|c|}
\hline Çiftçilere Ait B1 & giler & & $\begin{array}{c}\text { Oran1 } \\
(\%)\end{array}$ \\
\hline & Her zaman & 144 & 87.8 \\
\hline Pestisit uygularken çalışmayı yarım iş & Ara sira & 18 & 11.0 \\
\hline gününden fazla süre devam ettirme durumu & Nadiren & 2 & 1.2 \\
\hline & Hiçbir zaman & 0 & 0 \\
\hline & Her zaman & 4 & 2.4 \\
\hline İş sonunda kullanılan eldiven, çizme, maske & Ara sira & 10 & 6.1 \\
\hline ve giysileri yıkama durumu & Nadiren & 18 & 11.0 \\
\hline & Hiçbir zaman & 132 & 80.5 \\
\hline & Her zaman & 0 & 0 \\
\hline Y1kanan eldiven, çizme, maske ve & Ara sira & 4 & 2.4 \\
\hline giysilerinizi 24 saat güneş 1şı̆ginda kimsenin & Nadiren & 2 & 1.2 \\
\hline ulaşamadığı yerde kurutma durumu & Hiçbir zaman & 158 & 96.4 \\
\hline & Her zaman & 152 & 92.7 \\
\hline Bitk1 koruma uygulamalarında kullanilan & Ara sira & 9 & 5.5 \\
\hline $\begin{array}{l}\text { eldiven, çıme, maske ve giysilerınızı başka } \\
\text { bir is icin kullanma durumu }\end{array}$ & Nadiren & 3 & 1.8 \\
\hline & Hiçbir zaman & 0 & 0 \\
\hline & Yakarım & 27 & 16.5 \\
\hline & Çöpe atarım & 24 & 14.6 \\
\hline & Tarla kenarına bırakırım & 109 & 66.5 \\
\hline Boş ilaç kutularını imha etme durumu & Dereye atarım & 2 & 1.2 \\
\hline & Başka işler için kullanırım & 0 & 0 \\
\hline & Gömerim & 2 & 1.2 \\
\hline & Her zaman & 0 & 0 \\
\hline Boş ilaç kutularını başka işler için kullanma & Ara sira & 0 & 0 \\
\hline durumu & Nadiren & 0 & 0 \\
\hline & Hiçbir zaman & 164 & 100 \\
\hline & Her zaman & 49 & 29.9 \\
\hline Kullanım sonunda depoyu temizleme & Ara sira & 51 & 31.1 \\
\hline durumu & Nadiren & 24 & 14.6 \\
\hline & Hiçbir zaman & 30 & 18.3 \\
\hline & Her zaman & 6 & 3.7 \\
\hline İlaçlamadan sonra çevre insanlarını uyarma & Ara sira & 13 & 7.9 \\
\hline durumu & Nadiren & 24 & 14.6 \\
\hline & Hiçbir zaman & 121 & 73.8 \\
\hline
\end{tabular}

4. Sonuç

Tokat İl'inde bitki koruma makinelerini kullanan çiftçilerin iş güvenliği, kullanım alışkanlıkları vb mevcut durumlarının araştırıldığı bu çalışmada aşağıda yer alan belirlemeler yapılmıştır:

-Bitki koruma makinelerinin hastalık, zararlı ve yabancı otlarla mücadelede kısa sürede sonuç vermesi, sonucun gözle görülebilir olması ve uygulamanın kolay

-Bitki koruma makinesi kullanan çiftçilerin tarımsal konularda teknik bilgi almaya eğilimli oldukları görülmektedir.

-Bitki koruma makinesi kullanan çiftçilerin güvenli kullanım ve iş sağlığı ve güvenliği hakkında bir miktar bilgilerinin olduğu fakat bunları uygulamadıkları belirlenmiştir. olması gibi nedenlerle çiftçiler tarafından çok yaygın olarak kullanıldığı belirlenmiştir.

-Bitki koruma makinesi kullanan çiftçiler tarım makinelerinin güvenli kullanımı konusunda yeterli düzeyde eğitim alamamaktadırlar. Bunun sonucunda, çiftçiler teknik bilgi açısından yetersiz kalmakta, iş sağlığı ve güvenliği kültürünün yaygınlaşması ve kalıcı olması sağlanamamaktadır.

-Çiftçilerin yaklaşı yarısı bitki koruma makinelerinin kalibrasyonu konusunu ilk defa duyduklarını belirtmişlerdir.

-Çiftçilerin yaklaşık \%82'sinin kimyasal ilacın hazırlanması ve uygulanması sirasinda herhangi bir kişisel koruyucu donanım kullanmamaktadırlar. 
-Çiftçilerin yaklaşı \%62'sinin kimyasal ilaç kutularının üzerinde yazılı olan bilgiye önem vermediği, kulaktan duyma bilgilerle ve kendi tecrübeleri ile ilaç dozunu ayarladıkları tespit edilmiştir.

-Çiftçilerin yaklaşık \%66'sının kullanılan kimyasalların boş kutularını tarla kenarına bıraktıkları belirlenmiştir.

Öneriler;

-Ülkemizde her yıl gerek tarım alanlarında gerekse makineyi kullanıma hazırlama ve pestisit hazırlama sırasında bitki koruma makinelerinin neden olduğu pestisit zehirlenmesi, hastalıklar, ölümler, yaralanmalı veya maddi hasarlı kazaların önüne geçmek için çiftçilere tarımsal iş sağlığı ve güvenliği kültürünün benimsetilmesi ve konu ile ilgili eğitimlerin yaygınlaştırılması gerekmektedir.

-Pestisit satış yerleri başta olmak üzere, pestisitlerin kullanım şekli ve dozu, kullanılan makinelerin ayar ve kalibrasyon işlemleri süreci, kullanıcıların eğitimi, pestisitlerin uygulanması sırasında kullanılması gereken kişisel koruyucu ekipman tedariki ve kullanımı, boş

\section{Teșekkür}

$\mathrm{Bu}$ çalışma Ondokuz Mayıs Üniversitesi Bilimsel Araştırma Projeleri kapsamında PYO.ZRT.1904.15.008 numaralı proje ile desteklenmiştir.

\section{Kaynaklar}

Ahioğlu, S.S., 2008. Tarım Sektöründe İş Sağlığı ve Güvenliği ve Risk Değerlendirmesi. İş Sağllğı ve Güvenliği Uzmanlık Tezi, Çalışma ve Sosyal Güvenlik Bakanlığı İş Sağlığı ve Güvenliği Genel Müdürlüğü İş Sağlığı ve Güvenliği Enstitüsü, Ankara.

Bayat, A., Andırın, İ., 2005. Tarla pülverizatörünün zorunlu denetimine ait bazı temel verilerin saptanması. Çukurova Üniversitesi Tarım Makineleri Bilimi Dergisi, 1(2): 135-141.

Demir, C., 2005. Tekirdağ ili tarım işletmelerinde kimyasal savaşımda kullanılan bitki koruma makinelerinin teknik özellikleri ve uygulama sorunlarının saptanması üzerine bir araștırma. Yüksek Lisans Tezi. Namık Kemal Üniversitesi Fen Bilimleri Enstitüsü, Tekirdağ.

Öz, E., 2005. Ege Bölgesi'nde meydana gelen traktör kazalarının tarımsal iş güvenliği açısından değerlendirilmesi. Ege Üniversitesi Ziraat Fakültesi Dergisi, 42(2): 191-202.

Peker, A., Özkan, A., 1995. Traktör ve tarım iş makineleri kazalarında meydana gelen can kayıplarının risk analizi. Tarımsal Mekanizasyon 16.Ulusal Kongresi, 618-626, 5-7 Eylül 1995, Bursa.

Yamane, T., 1967. Elemantary Sampling Theory. Printice Hall Incorporated, Englewood Cliffs, New Jersey, USA. kimyasal kutu vb atıkları toplama ve imha zorunluluğu konularını kapsayacak şekilde yönetmelikler oluşturulması ve bunların hızlı ve etkin bir şekilde hayata geçirilmesi gerekmektedir.

-İlgili bakanlıklar ve kamu kuruluşları, üniversiteler, birlikler vb çiftçilere tarla günleri, seminer, toplantı, eğitim, kurs vb bilgilendirme toplantıları yaparak konuya dikkat çekilmelidir. Bitki koruma makineleri kullanım sertifikası zorunluluğu getirilmesi için yasal düzenlemeler yapılmalıdır.

-Düzenlenen programlarla bitki koruma makinesi ve pestisit kullanıcılarına, pestisitlerin güvenli kullanımı ve hazırlanması, makinelerin ayar ve bakımları, kişisel koruyucu donanımların (maske, iş tulumu, çizme, eldiven vs) zorunlu olarak tedarik edilmesi, boş pestisit kaplarının imhası vb konularda eğitimler verilmelidir. Böylece bilinçsiz olarak bu makinelerin ve pestisitlerin kullanımının neden olduğu zehirlenme, hastalık ve yaralanmaların önüne geçilebilmesi mümkün olabilecektir.

Yurtlu, Y.B., Demiryürek, K., Bozoğlu, M., Ceyhan, V., 2012. Çiftçilerin tarım makineleri kullanımına ilişkin risk algıları. Ege Üniversitesi Ziraat Fakültesi Dergisi, 49(1):93-101.

Yurtlu, Y.B., Öz, E., Alayunt, F.N., Çakmak, B., Şimşek, Z., 2015. Tarımda İş Güvenliği ve Sağlığı. Türkiye Ziraat Mühendisliği VIII. Teknik Kongresi, Bildiriler Kitabı 2, 1435-1454, 12-16 Ocak, Ankara. 